\title{
Epithelial metabolism of the corneal graft is abnormal
}

\author{
ANTTI VANNAS,' BRIEN A HOLDEN, ${ }^{2}$ AND DEBORAH F SWEENEY ${ }^{2}$ \\ From the 'University Eye Clinic, Helsinki, Finland, and the ${ }^{2}$ Cornea and Contact Lens Research Unit, School of \\ Optometry, University of New South Wales, Australia
}

\begin{abstract}
SUMMARY Both eyes of 16 patients who had undergone unilateral penetrating keratoplasty were examined in this study. The mean corneal oxygen uptake rate in the centre of the graft was $3 \cdot 88$ (SD $0.55) \mathrm{mmHg} / \mathrm{s}$ and in the control eye was $4.29(\mathrm{SD} \mathrm{0.62)} \mathrm{mmHg} / \mathrm{s}$. In the temporal host periphery the results for the grafted and control eyes were 4.52 (SD 0.54$) \mathrm{mmHg} / \mathrm{s}$ and 4.26 (SD 0.52) $\mathrm{mmHg} / \mathrm{s}$ respectively. The differences in the oxygen uptake rate between the centre of the graft cornea and the contralateral control eye and between the centre and periphery of the graft eye were statistically significant $(\mathrm{p}<0.01)$. The central corneal touch threshold of the graft eye showed good recovery in four patients, while the remaining 12 had no or minimal recovery. The central and temporal epithelial and corneal thicknesses of the graft and the control eyes were not significantly different. The central endothelial cell density was 1383 cells $/ \mathrm{mm}^{2}$ in the graft and $3053 \mathrm{cells} / \mathrm{mm}^{2}$ in the control eye. As corneal oxygen uptake reflects changes in aerobic epithelial metabolism, it is possible that there is a link between loss of neural integrity of graft epithelium and lowered epithelial aerobic metabolism following penetrating keratoplasty.
\end{abstract}

The cornea of the aphakic eye swells less with a hypoxic stimulus than does the cornea of the paired normal eye. ${ }^{1-3}$ However, neither the removal of the crystalline lens nor the endothelial changes produced by surgery appear to be related to the difference in hypoxic corneal swelling response. Rather, the difference has been attributed to the lower aerobic metabolic activity of the epithelium due to partial denervation of the cornea following surgery. ${ }^{+}$

Differences in epithelial aerobic metabolism are reflected in the corneal oxygen uptake rate when corneal thickness, the main factor influencing diffusion of oxygen, remains approximately the same. ${ }^{5}$

The present study was initiated to investigate further the effects of denervation on aerobic metabolic activity. Both the central and peripheral corneal oxygen uptake rates and sensitivities in both eyes of 16 patients with unilateral penetrating keratoplasty were measured.

\section{Materials and methods}

\section{SUBJECTS}

Sixteen subjects who had undergone unilateral penetrating keratoplasty participated in the study after

Correspondence to Antti Vannas, MD, Department of Ophthalmology, University of Helsinki, Haartmaninkatu 4C, 00290 Helsinki 29, Finland. their informed consent was obtained. The patient characteristics and details of the surgery are listed in Table 1 . The average age of the patients was 43 years (range 24-60 years) and the time after surgery averaged 29 months (range 10-102 months). All the

Table 1 Details of subjects

\begin{tabular}{llllll}
\hline Subject & Sex & Age & $\begin{array}{l}\text { Reason } \\
\text { eye }\end{array}$ & $\begin{array}{l}\text { Timesince } \\
\text { surgery } \\
\text { (months) }\end{array}$ \\
\hline 1 & M & 28 & R & K & 10 \\
2 & M & 54 & R & H & 10 \\
3 & F & 39 & L & S & 13 \\
4 & M & 60 & L & H & 14 \\
5 & F & 54 & R & K & 15 \\
6 & M & 36 & L & K & 21 \\
7 & F & 56 & R & S & 22 \\
8 & M & 38 & L & K & 24 \\
9 & M & 44 & L & K & 24 \\
10 & F & 39 & R & K & 27 \\
11 & M & 24 & L & K & 28 \\
12 & M & 47 & R & K & 32 \\
13 & M & 29 & R & K & 36 \\
14 & M & 33 & L & H & 38 \\
15 & F & 47 & L & K & 52 \\
16 & M & 60 & L & B & 102 \\
Mean & & 43 & & & 29 \\
SD & & 12 & & & 22 \\
\hline
\end{tabular}

$\mathrm{K}=$ Keratoconus. $\mathrm{H}=$ Herpes simplex. $\mathrm{S}=$ Past corneal trauma. $\mathrm{B}=$ Bullous keratopathy. 
operations were performed by the one surgeon using the same technique. The diameter of the grafts was $8 \mathrm{~mm}$. The running $10-0$ nylon suture was removed after six months. Local corticosteroid therapy was also stopped at this time. Inflammatory changes were not observed in any of the corneas at the time of measurement.

\section{METHODS}

Corneal oxygen uptake rate. Corneal oxygen uptake rate was measured with a polarographic oxygen sensor $^{67}$ applied directly to the anterior cornea. The oxygen sensor (Radiometer E5057/0, $8 \mathrm{~mm}$ in diameter with a $25 \mu \mathrm{m}$ diameter cathode) was covered with a $12.5 \mu \mathrm{m}$ thick polypropylene membrane. The sensor current was amplified by a radiometer amplifier (PHM 73) linked to a microcomputer (Apple II Plus). The sensor was calibrated periodically at $34^{\circ} \mathrm{C}$ in air $\left(155 \mathrm{mmHg} \mathrm{PO}_{2}\right)$ and nitrogensaturated water $\left(0 \mathrm{mmHg} \mathrm{PO}_{2}\right)$ baths. The corneal oxygen uptake rate was determined by recording the time required for the oxygen tension at the membrane to drop from 140 to $100 \mathrm{mmHg}$. The result is expressed in $\mathrm{mmHg} / \mathrm{s}$.

Three readings of the central and the temporal peripheral corneal oxygen uptake rate of each eye were taken. The average variability (SD) for three readings taken at each measurement session was 0.22 $\mathrm{mmHg} / \mathrm{s}$.

Corneal touch threshold. Corneal sensitivity was measured with a Cochet-Bonnet aesthesiometer, which consists of a $0 \cdot 12 \mathrm{~mm}$ diameter nylon monofilament encased in a cylinder. The aesthesiometer was mounted on a triaxis holder so that its position and movement could be controlled in the $x, y$, and $z$ meridians in an arrangement similar to that used by Millodot. ${ }^{8}$ The length of the monofilament can be varied from 6.0 to $0.5 \mathrm{~cm}$. This range corresponds to pressures of 1 to $20 \mathrm{~g} / \mathrm{mm}^{2}$ (cross-sectional area of the filament, $0.0113 \mathrm{~mm}^{2}$ ). To obtain a measurement the aesthesiometer was moved slowly toward the cornea at a constant velocity until visible bending of the filament occurred. The subject was asked to tap on the table if touch was felt. Presence or absence of the blink reflex was also noted. The aesthesiometer was first set at a maximum thread length of $6.0 \mathrm{~cm}$ and the length was then decreased by $0.5 \mathrm{~cm}$ increments until the patient felt three of the six stimuli. This filament length was recorded as the value corresponding to the corneal touch threshold. The central and temporal regions of the graft and control corneas were measured.

Epithelial thickness. The Payor-Holden micropachometer, consisting of a Haag-Streit pachometer adapted to a Rodenstock Model 2000 biomicroscope, was used to monitor central and temporal epithelial thickness. The design and operation of the system have been previously described. ${ }^{x}$ Ten readings of central and temporal epithelial thickness were obtained; the average standard deviation for the 10 readings was $5 \mu \mathrm{m}$ ( $10 \%$ of epithelial thickness).

Corneal thickness. Total corneal thickness was measured centrally and temporally with the micro-

Table 2 Central and temporal corneal characteristics of the graft patients

\begin{tabular}{|c|c|c|c|c|c|c|c|c|c|c|c|c|}
\hline \multirow{3}{*}{ Subject } & \multicolumn{6}{|c|}{ Oxygen uptake rate $(\mathrm{mmHg} / \mathrm{s})$} & \multicolumn{6}{|c|}{ Corneal touch threshold $\left(\mathrm{mg} / \mathrm{mm}^{2}\right)$} \\
\hline & \multicolumn{3}{|c|}{ Central cornea } & \multicolumn{3}{|c|}{ Temporal cornea } & \multicolumn{3}{|c|}{ Central cornea } & \multicolumn{3}{|c|}{ Temporal cornea } \\
\hline & Graft & Control & Diff. & Graft & Control & Diff. & Graft & Control & Diff. & Graft & Control & Diff. \\
\hline 1 & $4 \cdot 45$ & $5 \cdot 26$ & -0.81 & $4 \cdot 33$ & $4 \cdot 35$ & -0.02 & 200 & 11 & 189 & 12 & 11 & 1 \\
\hline 2 & $3 \cdot 14$ & $3 \cdot 55$ & $-0 \cdot 41$ & $5 \cdot 01$ & $3 \cdot 62$ & $1 \cdot 39$ & 200 & 11 & 189 & 11 & 11 & 0 \\
\hline 3 & $4 \cdot 28$ & $5 \cdot 09$ & -0.81 & $5 \cdot 23$ & $4 \cdot 85$ & $0 \cdot 38$ & 11 & 11 & 0 & 11 & 11 & 0 \\
\hline 4 & $4 \cdot 21$ & $4 \cdot 25$ & -0.04 & $4 \cdot 70$ & $3 \cdot 88$ & $0 \cdot 82$ & 200 & 11 & 189 & 16 & 11 & 5 \\
\hline 5 & 3.40 & $4 \cdot 48$ & -1.08 & $4 \cdot 17$ & $4 \cdot 42$ & -0.25 & 36 & 16 & 20 & 21 & 13 & 8 \\
\hline 6 & $4 \cdot 14$ & $4 \cdot 35$ & -0.21 & $4 \cdot 35$ & $4 \cdot 15$ & $0 \cdot 20$ & 200 & 11 & 189 & 12 & 11 & 1 \\
\hline 7 & $3 \cdot 23$ & $3 \cdot 36$ & -0.13 & 3.99 & $3 \cdot 30$ & 0.69 & 145 & 11 & 134. & 21 & 11 & 10 \\
\hline 8 & 4.03 & $4 \cdot 51$ & -0.48 & $4 \cdot 39$ & $4 \cdot 56$ & $-0 \cdot 17$ & 200 & 12 & 188 & 11 & 13 & -2 \\
\hline 9 & $4 \cdot 04$ & $4 \cdot 64$ & -0.60 & $4 \cdot 33$ & $4 \cdot 26$ & 0.07 & 200 & 11 & 189 & 11 & 11 & 0 \\
\hline 10 & $4 \cdot 11$ & $4 \cdot 48$ & -0.37 & $4 \cdot 21$ & $4 \cdot 45$ & $-0 \cdot 24$ & 145 & 11 & 134 & 11 & 11 & 0 \\
\hline 11 & $4 \cdot 39$ & $4 \cdot 73$ & -0.34 & 4.44 & $4 \cdot 62$ & -0.18 & 200 & 11 & 189 & 11 & 11 & 0 \\
\hline 12 & 3.78 & $3 \cdot 80$ & -0.02 & $4 \cdot 15$ & $5 \cdot 17$ & -1.02 & 13 & 11 & 2 & 21 & 11 & 10 \\
\hline 13 & 2.93 & 3.01 & -0.08 & 3.77 & $3 \cdot 35$ & 0.42 & 200 & 11 & 189 & 11 & 13 & -2 \\
\hline 14 & $4 \cdot 51$ & $4 \cdot 68$ & $-0 \cdot 17$ & $4 \cdot 63$ & $4 \cdot 60$ & 0.03 & 200 & 12 & 188 & 6 & 12 & -6 \\
\hline 15 & 3.02 & $3 \cdot 83$ & -0.81 & $6 \cdot 03$ & 4.09 & 1.94 & 11 & 11 & 0 & 11 & 11 & 0 \\
\hline 16 & $4 \cdot 47$ & $4 \cdot 68$ & -0.21 & $4 \cdot 54$ & $4 \cdot 54$ & 0.00 & 200 & 11 & 189 & 21 & 45 & -15 \\
\hline Mean & 3.88 & $4 \cdot 29$ & -0.41 & $4 \cdot 52$ & $4 \cdot 26$ & 0.25 & 148 & 11 & 136 & 14 & 13 & 1 \\
\hline SD & 0.55 & 0.62 & 0.33 & 0.54 & 0.52 & 0.70 & 80 & 1 & 80 & 5 & 6 & 6 \\
\hline$t$ value & & & $4 \cdot 81$ & & & $1 \cdot 38$ & & & $6 \cdot 58$ & & & 0.65 \\
\hline p & & & 0.001 & & & ns & & & $0 \cdot 001$ & & & ns \\
\hline
\end{tabular}


pachometer. Ten readings of corneal thickness were obtained on each measurement occasion; the average standard deviation for 10 readings was $4 \mu \mathrm{m}(0 \cdot 8 \%$ of corneal thickness).

Endothelial morphology. The central endothelium was photographed with Kodak Tri-X pan film using a non-contact specular microscope as described previously. ${ }^{910}$ Fifteen photographs were taken of each eye. The photographs were printed at $13 \times$ magnification from negatives which contained images of endothelial cells at approximately $30 \times$ magnification. A precision microscopic grid of known dimensions was photographed at the corneal plane to enable exact quantification of the endothelial mosaic. Five photographs of good quality were chosen from the 15 photographs of each eye. Technicians traced 50 cells from each photograph on to a plastic overlay using a fine black marking pen, giving a total of approximately 250 cells traced per eye. The cell tracings were analysed with an IBAS-2 automatic image analysis system (Kontron, West Germany). This instrument measured individual cell areas (adjusted for the width of the pen lines) and calculated endothelial cell density (ECD) and the coefficient of variation of mean cell size, which was used as an index of endothelial cell polymegathism.

Data analysis. The difference between the two eyes were tested for statistical significance by a $t$ test for matched pairs. A $95 \%$ confidence level was chosen as the criterion for accepting a diference as being significant.

\section{Results}

The corneal characteristics of all the subjects are listed in Table 2. The central corneal oxygen uptake rate of the graft eye $(3.88(\mathrm{SD} 0.55) \mathrm{mmHg} / \mathrm{s})$ was significantly depressed in comparison with the contralateral control eye $(4.29$ (SD 0.62$) \mathrm{mmHg} / \mathrm{s}$, $\mathrm{p}<0.001$, Student's two-tailed paired $t$ test). In addition, the corneal oxygen uptake rate was depressed in the centre of the graft in comparison with the temporal host periphery (3.88 (SD 0.55) $\mathrm{mmHg} / \mathrm{s}$ vs 4.52 (SD 0.54$) \mathrm{mmHg} / \mathrm{s}$. The mean reduction was $9 \%$ and this was also statistically significant $(<0.05$, Student's two-tailed paired $t$ test $)$. The difference, however, between the central (4.29 (SD 0.62) $\mathrm{mmHg} / \mathrm{s}$ ) and temporal (4.26 (SD 0.52) $\mathrm{mmHg} / \mathrm{s})$ measurements of the control eye $(0 \cdot 7 \%)$ was not statistically significant.

Mean corneal touch threshold for all subjects was also significantly reduced in the centre of the graft eye in comparison with the centre of the control eye and with the temporal host periphery $(\mathrm{p}<0.001$, Student's two-tailed paired $t$ test).

There was no statistically significant difference in mean epithelial or total thickness between the graft and control central and temporal corneas.

The average central endothelial cell density in the graft eye was 1383 cells $/ \mathrm{mm}^{2}$ and in the control eye 3053 cells $/ \mathrm{mm}^{2}$ (Table 3 ). The difference in the endothelial cell density between the graft and control eyes was $55 \%$. This reduction was statistically significant $(\mathrm{p}<0.001$, Student's two-tailed paired $t$ test).

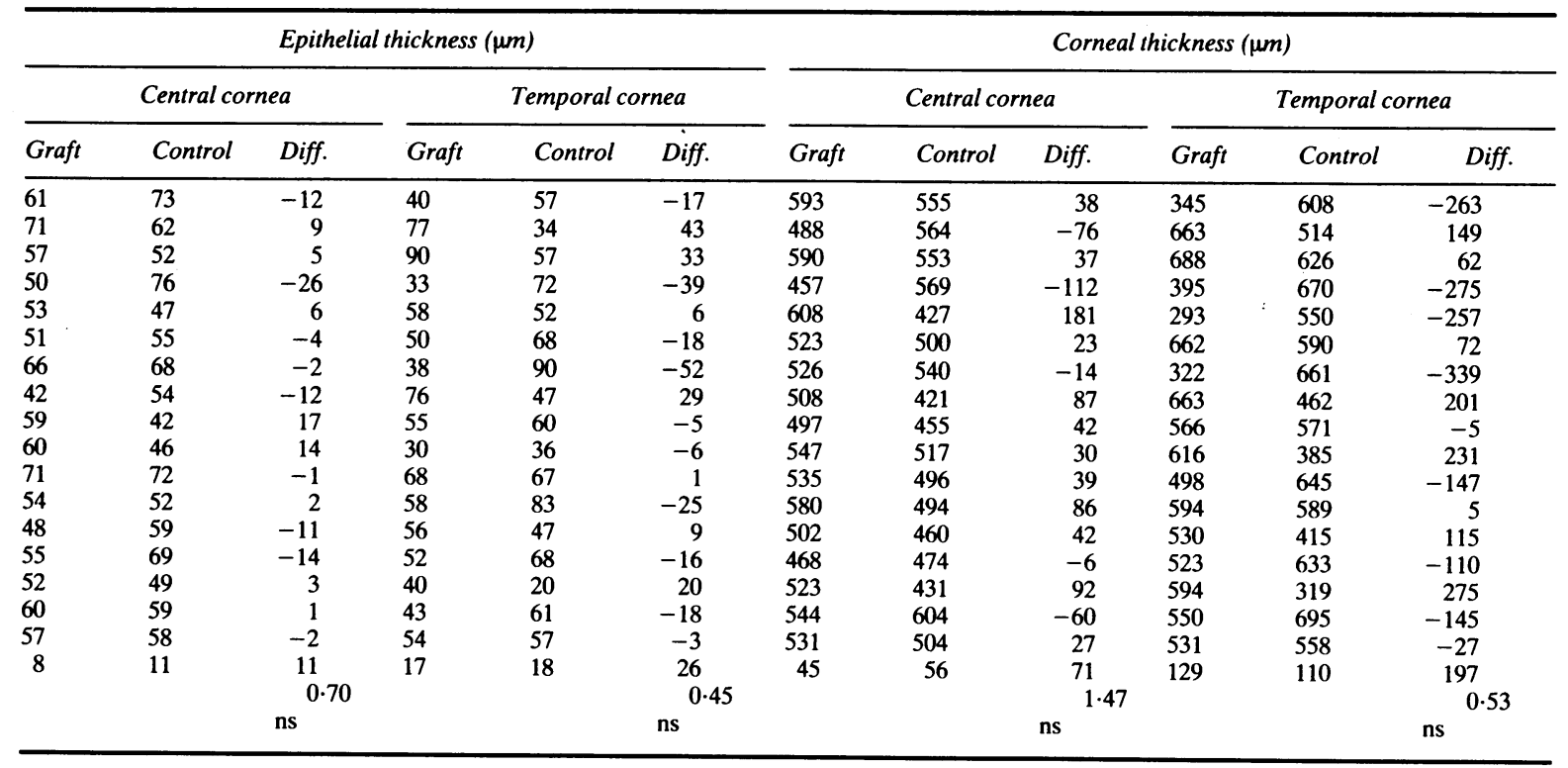


Table 3 Central endothelial cell density (ECD) and polymegathism

\begin{tabular}{|c|c|c|c|c|c|c|}
\hline \multirow{3}{*}{ Subject } & \multicolumn{3}{|c|}{ EDC cells $/ \mathrm{mm}^{2}$} & \multicolumn{3}{|c|}{ Polymegathism } \\
\hline & \multicolumn{3}{|c|}{ Central cornea } & \multicolumn{3}{|c|}{ Central cornea } \\
\hline & Graft & Control & Diff. & Graft & Control & Diff. \\
\hline 1 & 2237 & 3799 & -1562 & 0.291 & 0.243 & 0.048 \\
\hline 2 & 1031 & 2747 & -1716 & 0.458 & 0.263 & 0.195 \\
\hline 3 & 2531 & 3524 & -993 & 0.327 & 0.283 & $0 \cdot(044$ \\
\hline 4 & 1780 & 3201 & -1421 & 0.276 & 0.316 & -0.039 \\
\hline 5 & 463 & 3058 & -2595 & 0.280 & 0.247 & 0.033 \\
\hline 6 & 1091 & 3499 & -2408 & 0.312 & 0.285 & $0 \cdot 036$ \\
\hline 7 & 1443 & 1788 & -345 & 0.303 & ().286 & 0.017 \\
\hline 8 & 1402 & 3084 & -1682 & 0.356 & 0.319 & 0.037 \\
\hline 9 & 1173 & 2834 & -1661 & 0.295 & 0.319 & $-0 .(024$ \\
\hline 10 & 2085 & 2792 & -707 & 0.276 & ().271 & -0.002 \\
\hline 11 & 1679 & 4095 & -2416 & 0.344 & 0.280 & $0 \cdot 065$ \\
\hline 12 & 1122 & 3348 & -2226 & 0.298 & 0.275 & 0.024 \\
\hline 13 & 1162 & 3268 & -2106 & 0.321 & 0.229 & $0 \cdot 092$ \\
\hline 14 & 1176 & 3571 & -2395 & 0.257 & 0.312 & -0.054 \\
\hline 15 & 782 & 2892 & -2110 & 0.221 & 0.295 & -0.074 \\
\hline 16 & 973 & 1354 & -381 & $0 \cdot 301$ & 0.333 & $-0 \cdot 031$ \\
\hline Mean & 1383 & 3053 & -1670 & 0.307 & 0.285 & 0.011 \\
\hline SD & 552 & 693 & 733 & 0.052 & $0 \cdot 030$ & 0.121 \\
\hline t value & & & $8 \cdot 83$ & & & 0.35 \\
\hline$P$ & & & (0.001 & & & NS \\
\hline
\end{tabular}

There was no statistically significant difference in the endothelial polymegathism of the graft and control eyes.

\section{Discussion}

The results of this study show that the corneal oxygen consumption of the graft epithelium is not only significantly lower than the normal contralateral cornea but also lower than the host periphery. The periphery of the host cornea was subjected to the same post surgical conditions as the graft, yet retained normal oxygen uptake characteristics. This suggests that the depressed oxygen uptake of the graft is not due to postsurgical treatment such as steroids. As differences in corneal oxygen uptake rates are primarily caused by differences in epithelial metabolic activity, these results indicate that the epithelial metabolic activity of the graft cornea is depressed despite the long postoperative period. Even in the same eye the epithelium at the centre and periphery has different levels of metabolic activity following penetrating keratoplasty. This reduction, however, does not influence epithelial thickness, as measurements were similar in the graft and control eyes.

After penetrating keratoplasty the properties of the graft cornea are altered. Bourne and Brubaker" showed that endothelial permeability to fluorescein is reduced with reduced endothelial cell density. This study showed a marked reduction of the endothelial cell density in the graft eye. Similar findings have been reported by others. ${ }^{12-16} \mathrm{~A}$ relevant question is whether endothelial changes influence corneal oxygen uptake rate. In our patients corneal oxygen uptake differences did not correlate with endothelial cell loss (Pearson correlation, $r=0 \cdot 14, p=0 \cdot 60$ ). This finding is not unexpected, as calculations with a computer model ${ }^{17}$ show that a two-fold increase or decrease in endothelial oxygen consumption has no significant effect on the uptake rate. ${ }^{1 \times}$

There was no statistically significant difference between the mean central cornea thickness of the graft and control eyes. However, in individual cases, the thickness of the graft and control eye did vary (Table 2). As reported previously, significant differences in corneal thickness can alter the rate of passive diffusion of oxygen from the atmosphere to the aqueous humour. ${ }^{5}$ To test whether this may have influenced our findings we used the technique described by Holden et al. ${ }^{5}$ to recalculate the oxygen uptake rates to allow for this difference. After recalculation the differences between the graft and control eye central oxygen uptake rates and between the central and peripheral oxygen uptake rates of the graft cornea were still statistically significant. Thus the overall results were not influenced by corneal thickness changes in individual cases.

Problems with neovascularisation, punctate epithelial lesions, and infections with extended contact lens wear following keratoplasty have been reported. ${ }^{1921}$ Epithelium with a lower than normal aerobic metabolism must be regarded as compromised and as a result may be more prone to develop infections during contact lens wear. ${ }^{1921}$ The compromised epithelium could also be more prone to secrete neovasculogenic subtances"2 causing superficial neovascularisation observed in many graft patients with contact lens wear.

The central corneal sensitivity of the graft cornea was significantly reduced in 12 patients in agreement with previous studies. ${ }^{232-4}$ However, three of our patients $(3,5$, and 12$)$ had normal sensitivity postoperatively, with one patient having normal sensitivity only 13 months after penetrating keratoplasty. In another study Ruben and Colebrook ${ }^{24}$ found no case of normal central sensation until at least three years after surgery.

The reduction in the graft eye sensitivity could partly be explained by an abnormal nerve regeneration pattern. Nerve fibres in the graft cornea are single axons running in the basal epithelial plexus, where they give rise to a profuse plexiform network with very few stromal nerves evident. ${ }^{23}$.5 Stromal nerves find it difficult to regenerate, as Schwann cell channels are not in apposition within the incision and incomplete sensory recovery in humans results 
despite epithelial reinnervation. ${ }^{23}$ There is also evidence of some neurological control of the corneal epithelium in both the resting state and when it is physiologically challenged. ${ }^{+2627}$ Our findings of depressed epithelial metabolic activity in association with incomplete recovery of corneal nerves following keratoplasty lend further support to the hypothesis that normal corneal epithelial metabolism partly depends on normal innervation.

This research was supported by grants from the Finnish Eyc Foundation and the Optometric Vision Research Foundation of Australia (85-25).

\section{References}

1 Holden BA, Mertz GW, Guillon M. Corneal swelling response of the aphakic eye. Invest Ophthalmol Vis Sci 1980; 19: 1394-7.

2 Korb DR, Richmond PP, Herman NP. Physiological response of the cornea to hydrogel lenses before and after cataract extraction. Am J Optom Assoc 1980; 51: 267-70.

3 Guillon M, Morris JA. Corneal evaluation of prospective aphakic wearers of contact lenses. Br J Ophthalmol 1982; 66: 520-3.

4 Vannas A, Holden BA, Sweeney DF, Polse KA. Surgical incision alters the swelling response of the human cornea. Invest Ophthalmol Vis Sci 1985: 26: 67-80.

5 Holden BA, Sulonen J, Vannas A, Sweeney DF, Efron N. Direct in-vivo measurement of corneal epithelial metabolic activity using a polarographic oxygen sensor. Ophthalmic Res 1985; 17: 168-73.

6 Hill RM, Fatt I. Oxygen deprivation of the cornea by contact lens and lid closure. Am J Optom Physiol Opt 1964; 41: 678-87.

7 Holden BA, Polse KA, Fonn D, Mertz GW. Effects of cataract surgery on corneal function. Invest Ophthalmol Vis Sci 1982; 22: $343-50$.

8 Millodot M. Objective measurement of corneal sensitivity. Acta Ophthalmol (Kbh) 1973; 51: 325-34.

9 Holden BA. High Magnification examination and photography with the slip lamp. In: Brandreth RH, ed. Clinical slit lamp biomicroscopy. San Leandro, CA: Blaco Printers, 1978: 329-41.

10 Vannas A, Makitie J, Sulonen J, Ahonen R, Jarvinen E. Contact lens induced transient changes in corneal endothelium. Acta Ophthalmol (Kbh) 1981; 59: 552-9.
11 Bourne WM. Brubaker RF. Decreased endothelial permeability in transplanted corneas. Am J Ophthalmol 1983; 96: 362-7.

12 Laing RA, Sandstrom M, Berrospi AR, Leibowitz HM. Morphological changes in corneal endothelial cells after penetrating keratoplasty. Am J Ophthalmol 1975; 82: 459-64.

13 Bourne WM, O'Fallon WM. Endothelial cell loss during penetrating keratoplasty. Am J Ophthalmol 1978; 85: 760-6.

14 Bourne WM. One-year observation of transplanted human corneal endothelium. Ophthalmology 1980; 87: 673-9.

15 Culbertson WW, Abbott RL. Forster RK. Endothelial cell loss in penetrating keratoplasty. Ophthalmology 1982; 89: 601-4.

16 Bourne WM. Chronic endothial cell loss in transplanted corneas. Cornea 1983; 2: 289-94.

17 Kwok LS. Effect of epithelial cell injury on anterior corneal oxygen flux. Am J Optom Physiol Opt 1985; 62: 642-7.

18 Kwok LS. Physiological properties of the normal and healed cat cornea. Australia: University of New South Wales, 1986: PhD thesis.

19 Lemp MA. The effect of extended-wear aphakic hydrophilic contact lenses after penetrating keratoplasty. Am J Ophthalmol 1980; 90: 331-5.

20 Mannis MJ, Matsumoto ER. Extended wear aphakic contact lenses after penetrating keratoplasty. Arch Ophthalmol 1983; 101: $1225-8$.

21 Purcell JJ Jr. Extended-wear contact lenses after corneal grafts, correspondence. Am J Ophthalmol 1981; 91: 119-20.

22 Eliason JA, Desmukh A, Elliot JP. Chemotactic activity from the corneal epithelium. Invest Ophthalmol Vis Sci 1984; 25 (suppl): 323 .

23 Tervo T, Vannas A, Tervo K, Holden BA. Histochemical evidence of limited reinnervation of human corneal grafts. Acta Ophthalmol (Kbh) 1985; 63: 207-14.

24 Ruben M, Colebrook E. Keratoplasty sensitivity. $\mathrm{Br} J$ Ophthalmol 1979; 63: 265-7.

25 Franceschetti A, Babel J. Histologic examination of a transparent corneal transplant: the behaviour of nerves. Ann Oculist (Paris) 1947; 180: 145-54.

26 Sweeney DF, Vannas A. Holden BA. Tervo T. Telaranta $T$. Evidence for sympathetic neural influence on human corncal epithelial function. Acta Ophthalmol (Kbh) 1985: 63: 215-20.

27 Beuerman RW, Schimmelpfennig B. Sensory denervation of the rabbit cornea affects epithelial properties. Exp Neurol 1980; 69: 196-201.

Accepted for publication 10 September 1986. 